\title{
Candida parapsilosis complex water isolates from a haemodialysis unit: biofilm production and in vitro evaluation of the use of clinical antifungals
}

\author{
Regina Helena Pires ${ }^{1 /+}$, Jaime Maia dos Santos², José Eduardo Zaia ${ }^{3}$, \\ Carlos Henrique Gomes Martins ${ }^{3}$, Maria José Soares Mendes-Giannini'
}

'Departamento de Análises Clínicas, Faculdade de Ciências Farmacêuticas, Universidade Estadual Paulista, Araraquara, SP, Brasil
Departamento de Fitossanidade Vegetal, Faculdade de Ciências Agrárias e Veterinárias, Universidade Estadual Paulista,
Jaboticabal, SP, Brasil ' ${ }^{3}$ Laboratório de Pesquisa em Microbiologia Aplicada, Universidade de Franca, Franca, SP, Brasil

Candida parapsilosis, currently divided into three distinct species, proliferates in glucose-rich solutions and has been associated with infections resulting from the use of medical devices made of plastic, an environment common in dialysis centres. The aims of this study were (i) to screen for Candida orthopsilosis and Candida metapsilosis (100 environmental isolates previously identified as C. parapsilosis), (ii) to test the ability of these isolates to form biofilm and (iii) to investigate the in vitro susceptibility of Candida spp biofilms to the antifungal agents, fluconazole (FLC) and amphotericin $B(A M B)$. Isolates were obtained from a hydraulic circuit collected from a haemodialysis unit. Based on molecular criteria, 47 strains were re-identified as C. orthopsilosis and 53 as C. parapsilosis. Analyses using a formazan salt reduction assay and total viable count, together with microscopy studies, revealed that 72 strains were able to form biofilm that was structurally similar, but with minor differences in morphology. A microtitre-based colorimetric assay used to test the susceptibility of fungal biofilms to AMB and FLC demonstrated that the C. parapsilosis complex displayed an increased resistance to these antifungal agents. The results from these analyses may provide a basis for implementing quality controls and monitoring to ensure the microbiological purity of dialysis water, including the presence of yeast.

Key words: Candida parapsilosis - Candida orthopsilosis - biofilm - haemodialysis solution

Haemodialysis is a technique that allows the treatment of the patient's blood through a semi-permeable membrane against a saline solution, thus eliminating excess electrolytes, some toxic wastes and water (VorbeckMeister et al. 1999).

The removal of chlorine and chloramines from the feed water, together with the presence of stagnant areas within the distribution network, inadequate maintenance of tanks, dead spaces and tubing within the haemodialysis machine, mean that the water systems used may become contaminated with microbes and therefore become susceptible to the growth of biofilm (Marion-Ferey et al. 2003, Nystrand 2008). A variety of microorganisms is present in such biofilms and release compounds such as endotoxins, muramylpeptides and polysaccharides into the water. The molecular weight of such compounds ranges from $0.5-200 \mathrm{kDa}$, permitting their passage through membranes used in renal replacement (Schindler et al. 2004, Cappelli et al. 2005).

Patients with renal failure are more frequently at risk of fungal infections than healthy individuals (Drozdowska 2007). Based on previous results from our laboratory (Varo

\footnotetext{
Financial support: UNESP (PADC/FCFAr-UNESP 2009/54), CAPES + Corresponding author: rehepi@gmail.com

Received 9 January 2011

Accepted 16 August 2011
}

et al. 2007, Pires-Gonçalves et al. 2008), Candida parapsilosis was shown to be the predominant yeast involved in the contamination of water samples collected from a haemodialysis centre. In addition, $C$. parapsilosis has emerged as a major pathogen in nosocomial candidemia in Brazilian tertiary care hospitals (Medrano et al. 2006, Bruder-Nascimento et al. 2010, Cordeiro et al. 2010, Pereira et al. 2010). Recently, the $C$. parapsilosis complex has been redefined as three distinct species: $C$. parapsilosis, Candida orthopsilosis and Candida metapsilosis (Tavanti et al. 2005); however, the current literature contains very little data pertaining to the distributions and antifungal susceptibilities of these biofilm Candida species.

Candida species have different degrees of susceptibility to antifungal drugs, which have been used for both the control of infections and prophylaxis (Pfaller et al. 2003, Yang et al. 2004). Previous studies, which compared the clinical use of drugs such as fluconazole (FLC) and amphotericin B (AMB) showed that FLC is the best therapy in the empiric treatment of fungal infections due to lower toxicity and low cost (Pfaller et al. 2003, Colombo et al. 2006, Nucci et al. 2010).

Although $C$. parapsilosis is not considered to be particularly prone to the development of antifungal resistance, several reports have suggested a decreased susceptibility to azoles and AMB (Diekema et al. 2009, Pappas et al. 2009). The emergence of $C$. parapsilosis strains that have decreased susceptibility to azoles and that may be transmitted throughout the hospital environment may be related to the extensive use of FLC in combination 
with suboptimal hand hygiene and central venous catheter care in a population of seriously ill patients. Moreover, it is known that biofilms have increased levels of resistance to the most commonly used antifungal agents (Ramage et al. 2001, Pierce et al. 2008).

In this study we used a large collection of strains originally identified as $C$. parapsilosis collected from a hydraulic circuit from a haemodialysis centre (i) to screen for C. orthopsilosis and C. metapsilosis, (ii) to test the ability to form biofilm and (iii) to investigate the in vitro susceptibility of Candida spp biofilms to the antifungals FLC and AMB. This is the first study describing the recovery of distinct $C$. parapsilosis strains in the water used in haemodialysis.

\section{MATERIALS AND METHODS}

Isolates - A total of 100 isolates taken from the water samples described below and previously identified by conventional methods as $C$. parapsilosis was included in this study. The isolates were collected from the haemodialysis unit located in the state of São Paulo (SP), Brazil, between March 2006-March 2007. They were obtained from 110 samples of water that were collected at the beginning of a dialysis treatment and consisted of a series of 22 samples at each of five points in the water system: municipal water supply to the dialysis centre (I), downstream of the reverse osmosis filter (II), water distribution systems in three dialysis rooms, designated rooms A, B and C (III), (IV) and (V). Each sample was collected after 3-5 min free flow (APHA 2005). Samples from (I) were treated with $1 \mathrm{~mL} 1.8 \%$ sodium thiosulfate per litre to remove residual chlorine. In addition, 36 samples were taken from 19 kidney machines, four samples of cleaning water from the dialyser reuse system and 13 from the water storage tank, before use or during patient changeover once they were disinfected and ready for a new session. Water samples were filtered through a cellulose acetate membrane $(0.45 \mu \mathrm{m}$ pore size, Millipore, $\mathrm{SP}$, Brazil $)$ on a filtration ramp (Sartorius). The membrane was placed on a plate containing R2A agar (Reasoner \& Geldreich 1985 - Difco, Detroit, MI, USA) at $30^{\circ} \mathrm{C}$ for five days . The organisms were identified and the species defined based on the following: colony morphology, germ tube test, chlamydospores on Tween 80 cornmeal agar (Difco) and by the pattern of assimilation of a variety of carbon and nitrogen sources. The results were compiled and analysed as previously described by Kurtzman and Fell (1998). All fungal isolates were stored at $-80^{\circ} \mathrm{C}$ in the microbiology laboratory at the University of Franca, SP, Brazil; prior to use, frozen stocks were recovered from storage by growth on Chromagar Candida medium (CHROMagar Microbiology, Paris, France).

DNA extraction - Genomic DNA was extracted from yeasts grown in a broth composed of $2 \%$ glucose, $2 \%$ mycological peptone (Difco) and 1\% yeast extract (Difco) with horizontal shaking. Briefly, cells were harvested and lysed by vortexing with $0.3 \mathrm{~g}$ glass beads $(0.45-0.52$ $\mathrm{mm}$ in diameter; Sigma, St. Louis, MO) and $500 \mu \mathrm{L}$ TES [100 mM Tris, $\mathrm{pH}$ 8.0, $10 \mathrm{mM}$ ethylenediamine tetraa- cetic acid (EDTA), 2\% sodium dodecyl sulphate]. After vortexing, proteinase $\mathrm{K}(100 \mu \mathrm{g} / \mathrm{mL})$ was added to the lysate and incubated at $55^{\circ} \mathrm{C}$ for $1 \mathrm{~h}$. The salt concentrations were then adjusted to $1.4 \mathrm{M}$ with $5 \mathrm{M} \mathrm{NaCl}$ and $10 \%$ cethyltrimethylammonium bromide (Sigma Chemical Corporation, St. Louis, MO, USA) was added. After incubation $\left(10 \mathrm{~min}\right.$ at $\left.65^{\circ} \mathrm{C}\right)$, the samples were centrifuged $(3,000 \mathrm{~g} 10 \mathrm{~min})$; chloroform $(700 \mu \mathrm{L})$ was added to the supernatant and the samples were incubated for $30 \mathrm{~min}$ at $0^{\circ} \mathrm{C}$. Following centrifugation $(3,000 \mathrm{~g} 10 \mathrm{~min})$, RNase $(10 \mathrm{mg} / \mathrm{mL}$, Sigma) was added and the samples were incubated for $1 \mathrm{~h}$ at $37^{\circ} \mathrm{C}$. DNA was precipitated with two volumes of isopropanol, dried and redissolved in $50 \mu \mathrm{L}$ of TE buffer [10 mM Tris/HCl (pH 8.0), 1 mM EDTA].

Secondary alcohol dehydrogenase (SADH) gene restriction profile - Amplification of the $S A D H$ gene was performed by polymerase chain reaction (PCR) with the primers described by Tavanti et al. (2005). The amplification conditions were as follows: a cycle of denaturation for $7 \mathrm{~min}$ at $94^{\circ} \mathrm{C}$, followed by 30 cycles at $94^{\circ} \mathrm{C}$ for $1 \mathrm{~min}, 50^{\circ} \mathrm{C}$ for $1 \mathrm{~min}$ and $72^{\circ} \mathrm{C}$ for $1 \mathrm{~min}$, with a final step of $10 \mathrm{~min}$ at $72^{\circ} \mathrm{C}$. The PCR products were separated by agarose gel electrophoresis $(2 \%)$ in Tris-BorateEDTA (TBE) buffer $(89 \mathrm{mM}$ Tris base, $89 \mathrm{mM}$ boric acid, $2 \mathrm{mM}$ EDTA) $0.5 \mathrm{M} 20 \mathrm{~mL}$; distilled water to $1,000 \mathrm{~mL}$, at 150 volts for $2 \mathrm{~h}$ at room temperature. Amplicons in the gel were stained with ethidium bromide $(0.05 \mu \mathrm{g} / \mathrm{mL})$. Gels were visually analysed and, to standardise the quality of the images, imaged with ultraviolet (UV) light using the Image Master VDS System (Amersham Pharmacia Biotech, UK). C. parapsilosis ATCC 90018, C. orthopsilosis ATCC 96141 and C. metapsilosis ATCC 96143 were used as controls. The PCR products (fragment of $716 \mathrm{bp}$ ) obtained from C. parapsilosis isolates were digested with BanI restriction enzyme (New England Biolabs, Hitchin, UK) in a $30-\mu \mathrm{L}$ reaction volume containing $25 \mu \mathrm{L}$ of the PCR product, $3 \mu \mathrm{L}$ of $10 \mathrm{x}$ buffer (supplied with the enzyme) and $2 \mu \mathrm{L}$ of BanI (20 $\mathrm{U} / \mu \mathrm{L}$ ) (Tavanti et al. 2005, 2007, Silva et al. 2009). Digestion products were loaded onto a $2 \%$ agarose gel containing ethidium bromide. TBE buffer was used as the running buffer and a 100 bp DNA ladder was used as a molecular size marker (Promega, Madison, WI, USA). DNA bands were visualised by UV transillumination.

In vitro biofilm assay - The protocol for biofilm growth followed that of Pierce et al. (2008) with slight modifications. Briefly, Candida biofilms were formed on commercially available, presterilised, polystyrene, flatbottomed, 96-well microtitre plates (Corning Inc, Corning, NY, USA). Standard cell suspensions $[100 \mu \mathrm{L}$ of a suspension containing $1 \times 10^{6}$ cells $/ \mathrm{mL}$ in Roswell Park Memorial Institute (RPMI) 1640 supplemented with Lglutamine and buffered with $0.165 \mathrm{M}$ morpholinepropanesulfonic acid (MOPS) (Sigma)] were seeded in selected wells and incubated for a series of time intervals $(4,6,8$, $12,18,24,36,48,72,84$ and $96 \mathrm{~h}$ ) at $37^{\circ} \mathrm{C}$. A semi-quantitative measure of the formed biofilms was calculated using a 2,3-bis (2-methoxy-4-nitro-5-sulphophenyl)-2H-tetrazolium-5-carboxanilide (MTT) (Sigma) reduction 
assay (Berridge et al. 2005, Krom et al. 2007, Nuryastuti et al. 2009). MTT solution ( $20 \mu \mathrm{L})$ [a stock solution containing $5 \mathrm{mg}$ of MTT per $\mathrm{mL}$ of phosphate buffered saline (PBS)] was added to each well and the samples were incubated at $37^{\circ} \mathrm{C}$ for $6 \mathrm{~h}$. After staining, plates were washed three times with PBS. Isopropyl alcohol $(200 \mu \mathrm{L})$ was then added to solubilise the MTT formazan product and $100 \mu \mathrm{L}$ was transferred to a new microtitre plate. The level [optical density (OD)] of the formazan present in the destaining solution was measured at $540 \mathrm{~nm}$ using a microplate reader (Asys) (Eugendorf, Salzburg, Austria). Candida albicans SC5314 was used as a biofilm control strain (Ramage et al. 2002, Pierce et al. 2008).

At each time point, viable counts of sessile cells were assessed. The wells were washed extensively and serial 10 -fold dilutions in sterile PBS were performed. The size of inocula for each cell suspension was confirmed by plating aliquots of 1:10, 1:100 and 1:1000 dilutions on Sabouraud dextrose agar (Difco) and obtaining a colony forming unit (CFU) measure after $48 \mathrm{~h}$ at $37^{\circ} \mathrm{C}$. All studies were conducted in duplicate and an average colony count $(\log 10 \mathrm{CFU} / \mathrm{mL})$ versus time (h) was calculated.

Antifungal susceptibility studies - Two antifungal agents frequently employed in clinical treatments were used in this study, FLU (Pfizer Inc, New York, NY, USA) and AMB (Bristol-Myers Squibb, Princeton, NJ, USA). Concentrations in the range of $0.125-512 \mu \mathrm{g} / \mathrm{mL}$ for azoles and $0.015-128 \mu \mathrm{g} / \mathrm{mL}$ for AMB were used. Stock solutions were prepared in water (azole) or dimethyl sulfoxide (AMB) and serial two-fold dilutions in RPMI 1640 medium (Sigma) buffered to $\mathrm{pH} 7.0$ with $0.165 \mathrm{M}$ MOPS buffer were made. Candida biofilm formation was carried out as described above. After biofilm formation, the suspension medium was aspirated and the biofilms were washed three times with sterile PBS. A total of $100 \mu \mathrm{L}$ of the antifungals were then added to the microtitre plates containing Candida biofilm and incubated for a further $24 \mathrm{~h}$ at $35^{\circ} \mathrm{C}$. Following incubation, the metabolic activities of the cells in the biofilms were estimated using the MTT absorbance assay. Minimum biofilm inhibitory concentration (MBIC) values of the antifungals were measured as the ODs of the antifungal-treated wells relative to those of the control (antifungal-free) wells (considered to be $100 \%$ ). All assays were carried out in quadruplicate. C. albicans SC5314 was used as a biofilm control strain (Ramage et al. 2002, Pierce et al. 2008).

The Clinical and Laboratory Standards Institute (CLSI) broth microdilution tests for planktonic cell were performed according to the CLSI M27-A3 recommendations approved in April 2008. Minimal inhibitory concentration (MIC) values for azoles were determined visually, after $24 \mathrm{~h}$ of incubation, as the lowest concentration of drug that caused a significant diminution $(\geq$ $50 \%$ inhibition) of growth below control levels and the MIC of AMB was determined as the lowest concentration that prevented any discernible growth. Strains with MICs of $>1 \mu \mathrm{g} / \mathrm{mL}$ for AMB were considered resistant (CLSI 2008, Diekema et al. 2009, Guinea et al. 2010). Quality control strains C. parapsilosis ATCC 22019, Candida krusei ATCC 6258 were included in each test.
Scanning electron microscopy (SEM) - C. parapsilosis and C. orthopsilosis isolates whose biofilm mode of growth came closest to the pattern of C. albicans SC 5314 biofilm in the MTT assay (OD) were selected for processing for both confocal microscopy and SEM. To determine the effect of antifungal drugs on the morphology and architecture of Candida biofilms, they were prepared according to a previously published protocol (Reed 1996). Briefly, Candida biofilms were formed on sterile polyvinylchloride (PVC) disks within 12-well cell culture plates (Corning) by dispensing cell suspensions containing 5.0 x $10^{6}$ cells $/ \mathrm{mL}$ in RPMI 1640 onto appropriate disks at $37^{\circ} \mathrm{C}$. The biofilms formed on these disks were placed in fixative $[2 \%$ formaldehyde $(\mathrm{v} / \mathrm{v}), 3 \%$ glutaraldehyde $(\mathrm{v} / \mathrm{v})$ in $0.1 \mathrm{M}$ potassium phosphate buffer $(\mathrm{pH}$ 7.2-7.4)] for $48 \mathrm{~h}$. After three washes, the cells were postfixed with $1 \%$ $(\mathrm{wt} / \mathrm{v}) \mathrm{OsO}_{4}$, dehydrated with a series of ethanol washes (30-100\%), critical-point dried in $\mathrm{CO}_{2}$ (MS 850, Electron Microscopy Sciences) and coated with gold in a Denton Vacuum Desk II coater. Following processing, specimens were visualised using an SEM (JSM 5410: JEOL, Tokyo, Japan). Experiments were repeated three times with at least three replicates for each time point.

Confocal scanning laser microscopy (CSLM) - Biofilms were stained and CSLM was performed as described previously by Kuhn et al. (2002). Biofilms were formed as described above for SEM. After incubation at $37^{\circ} \mathrm{C}$ for $24 \mathrm{~h}$, the disks were washed with PBS and transferred to a new 12-well plate. Four microlitres of FUN-1 $(10 \mathrm{Mm})$ (Molecular Probes, Eugene, Oregon, USA) and concanavalin A-AlexaFluor (CAAF) 488 conjugate $(0.5 \mathrm{mM})$ (Molecular Probes) in PBS, was added to each well containing a biofilm disk. The plate was incubated for $45 \mathrm{~min}$ at $37^{\circ} \mathrm{C}$ on a rocker t. Disks were removed from wells, placed in $35-\mathrm{mm}$ glass-bottom microwell dishes, inverted and observed using a Leica TCS SP5 microscope (Leica Microsystems, Wetzlar, Germany) using excitation at 543 and $488 \mathrm{~nm}$ and emission at 560 and $505 \mathrm{~nm}$ for FUN-1 (red) and CAAF (green), respectively. To determine the structure of the biofilms, a series of horizontal (xy) optical sections with a thickness of $1.175 \mathrm{~mm}$ was taken throughout the full length of the biofilm. Regions of red fluorescence (FUN-1) represent metabolically active cells, the green fluorescence (CAAF) indicates polysaccharide-containing cellular walls and yellow-brown areas represent metabolically inactive or non-viable cells. Confocal images of green and red fluorescence were recorded simultaneously using the multichannel mode. Z-stack images and measurements were corrected using LAS AF 1.8.2 build 1465 Leica Microsystems CMS Gmbh.

Statistical analysis - Statistical analyses were performed using GraphPad Prism version 4.00 for Windows (GraphPad Software, San Diego, CA, USA). Values were expressed as the means \pm standard deviation. The OD values from individual Candida biofilms were compared by the Student's $t$ test and the Dunnett's test for comparison post-test. The association between MTT assay absorbance readings and total viable count was determined by Pearson's correlation coefficient (r). 


\section{RESULTS}

Molecular identification of isolates - A fragment of the $S A D H$ gene (716 bp) was amplified by PCR and the restriction analysis of the $S A D H$ PCR products was used to redefine $100 \mathrm{C}$. parapsilosis complex isolates on the basis of conventional biochemical tests. According to the BanI restriction pattern, C. parapsilosis has one site (at position 196), C. metapsilosis has three (at positions 96, 469 and 529) and $C$. orthopsilosis has no restriction site. Of the 100 isolates, 53 were assigned to the most commonly encountered subtype, C. parapsilosis, and 47 to $C$. orthopsilosis (Fig. 1). No C. metapsilosis were found in this study.

Biofilm assays - Biofilm production was detected in a total of $72 \%$ of the 100 isolates. Table I shows biofilm metabolic activity results for all 100 environmental iso-

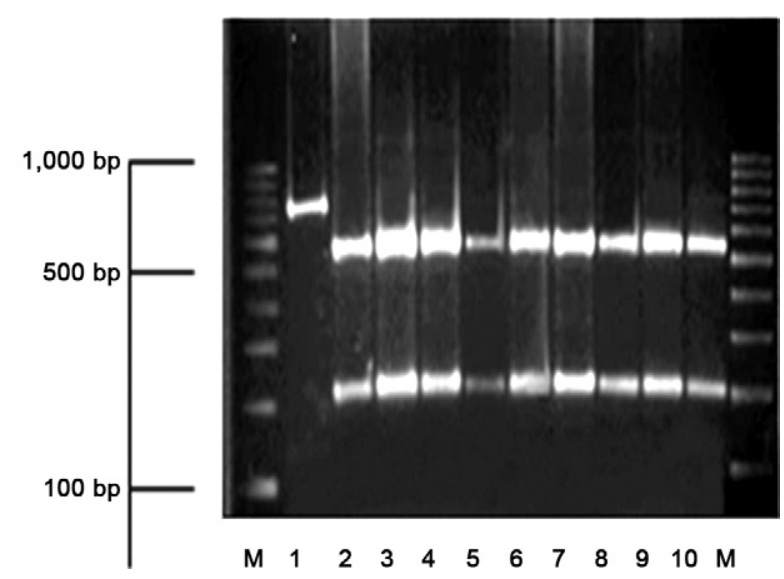

Fig. 1: agarose gel of BanI restriction digestion of secondary alcohol dehydrogenase ( $S A D H)$-polymerase chain reaction product obtained from 10 representative environmental Candida parapsilosis-complex strains. The digested fragment in Lane 1 was characteristic for Candida orthopsilosis whilst those in Lanes 2-10 are characteristic for $C$. parapsilosis. Lanes M: 100-bp ladder and the positions of migration of the 100,500 and 1,000 bp fragments are indicated. lates tested and one quality control strain. Results for the MTT colorimetric analyses $\left(\mathrm{OD}_{540 \mathrm{~nm}}\right.$ values) of biofilms of $C$. parapsilosis and C. orthopsilosis, formed in different wells (Table I) of the same 96-well microtitre plate (4 replicates), demonstrated no statistically significant difference between biofilm production ( $t$ test, $\mathrm{p}=0.199)$. However, analytical methods showed that $C$. albicans was the best biofilm producer (using a multiple comparison two-way Dunnett's t test, $\mathrm{p}<0.01)$ compared to the C. parapsilosis complex.

It has been previously argued that metabolic activity of a biofilm is correlated with cell numbers and that higher levels of MTT reduction indicate higher numbers of cells (Krom et al. 2007). In this study, we used a growth curve to show that MTT assay absorbance readings were proportional to the cellular density of the biofilm. The Pearson correlation test was used to compare the spectrophotometric profile with CFU counts and showed that there was a significant correlation $(\mathrm{r}=0.940, \mathrm{r}=0.951$ and $\mathrm{r}=0.958$ for $C$. parapsilosis, C. orthopsilosis and C. albicans, respectively). Maximum cell density was obtained in $48 \mathrm{~h}$, whilst the biofilms appeared to enter a phase of declining growth by $72 \mathrm{~h}$ as shown by the lower $\mathrm{OD}$ at $72 \mathrm{~h}$ than at $48 \mathrm{~h}$ (Fig. 2).

CSLM examination of biofilm-associated $C$. parapsilosis complex cells - CSLM examination was used to correlate the MTT reduction and CFU assay results with effects on biofilm metabolism and structure (Fig. 3A-E). Samples were stained with FUN-1 and concanavalin A. FUN-1 is a fluorescent dye that is taken up by fungal cells; in the presence of metabolic viability, it is converted from a diffuse yellow cytoplasmic stain to red, rod-like staining. The concanavalin A-AlexaFluor 488 conjugate selectively binds to polysaccharides, including $\alpha$-mannopyranosyl and $\alpha$-glucopyranosyl residues and fluoresces green. FUN-1 staining showed that Candida cells in biofilms were metabolically active, as indicated by the red fluorescence in Fig. 3. Both FUN-1 and MTT tests are used in cell viability but different biochemical pathways are used. FUN-1 test confirmed the results obtained with the MTT assay; both showed that the biofilm cells were metabolically active.

TABLE I

Biofilm quantification of Candida spp using (2-methoxy-4-nitro-5-sulphophenyl)-2H-tetrazolium-5-carboxanilide (MTT) reduction assay on independent wells of polystyrene microtitre plates grown for $24 \mathrm{~h}$

\begin{tabular}{|c|c|c|c|c|}
\hline Parameter & $\begin{array}{c}\text { Candida } \\
\text { parapsilosis }\end{array}$ & $\begin{array}{c}\text { Candida } \\
\text { orthopsilosis }\end{array}$ & $\begin{array}{l}\text { Candida albicans } \\
\text { SC } 5314 \\
\text { (positive control) }\end{array}$ & $\begin{array}{c}\text { Negative } \\
\text { control }\end{array}$ \\
\hline Min & 1.17 & 1.45 & 2.97 & 0.33 \\
\hline Max & 2.84 & 2.83 & 3.38 & 0.45 \\
\hline Mean & 1.96 & 2.01 & $3.12^{a}$ & $0.40^{a}$ \\
\hline Standard deviation & 0.29 & 0.26 & 0.11 & 0.03 \\
\hline
\end{tabular}

$a$ : according to analysis of variance followed by Dunnett's test, growth biofilm mode of C. albicans SC 5314 was significantly different $(\mathrm{p}<0.01)$ compared to the $C$. parapsilosis and C. orthopsilosis. No significant difference between biofilm formation of C. parapsilosis and C. orthopsilosis according to Student's $t$ test $(\mathrm{p}=0.199)$. 
Ultrastructural studies - The ultrastructure of biofilms of representative isolates of $C$. orthopsilosis and $C$. parapsilosis on PVC disks were compared with the reference strain C. albicans SC 5314 and observed by SEM to distinguish specific features of the species. After $24 \mathrm{~h}$ of incubation, the microarchitecture of the Candida biofilms became complex due to the amount of extracellular material surrounding the cells and resulted in compact structures that strongly adhered to the plastic support (Fig. 4A-C). Biofilms of C. orthopsilosis presented short filamentous forms and C. parapsilosis presented as a layer of blastospore aggregates with irregular clusters while $C$. albicans biofilms form complex structures with dense layers of blastospores and hyphae (Fig. 4). In agreement with the MBIC results, the treatment with AMB induced apparent cellular distortions on the blastospore layer (Fig. 5) whereas FLC-treated biofilm cells appeared minimally affected (Fig. 6).

Antifungal activity against C. orthopsilosis and C. parapsilosis planktonic cultures - The results obtained for C. parapsilosis $(\mathrm{n}=100)$ using the CLSI method at $24 \mathrm{~h}$ against both FLC and AMB are shown in Table II. None of the isolates showed resistance to the antifungal agents tested. MICs $(\mu \mathrm{g} / \mathrm{mL})$ at which $50 \%\left(\mathrm{MIC}_{50}\right)$ and $90 \%\left(\mathrm{MIC}_{90}\right)$ of the strains were inhibited were 0.5 and 2.0 , respectively, for FLC and 0.031 and 0.062 , respectively, for AMB. The planktonic MICs reported for control strains were within the recommended CLSI limits.

Activities of conventional antifungals against Candida biofilms - A clear difference in antifungal susceptibility was observed between the planktonic and sessile cells of both species. The mature Candida biofilms exhibited a strong resistance to antifungal agents. Resistance to FLC (MBIC greater than $512 \mu \mathrm{g} / \mathrm{mL}$ ) was detected in all the preformed biofilms of all strains because Candida

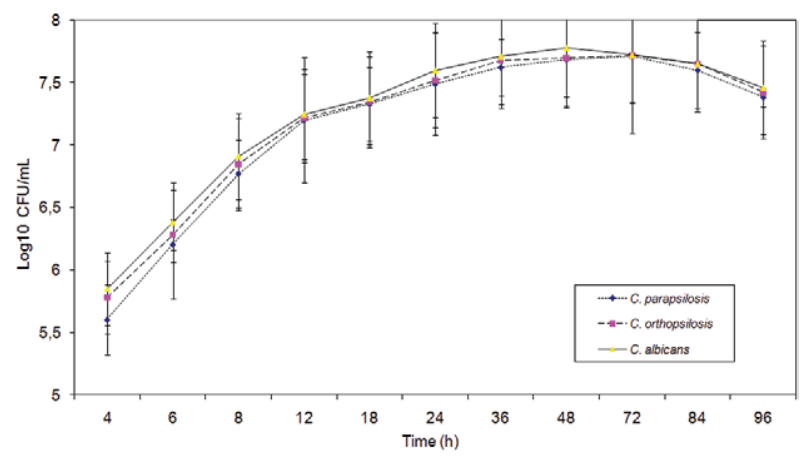

Fig. 2: growth curves of representative Candida yeast cells in biofilm. The number of cells at each specific time point was assessed by measuring the optical density (OD) absorption at $540 \mathrm{~nm}$ and total viable count [colony forming unit $(\mathrm{CFU}) / \mathrm{mL}$ ] after vigorously washing the cultures. The (2-methoxy-4-nitro-5-sulphophenyl)-2H-tetrazolium-5-carboxanilide (MTT) assay was performed as described in Materials and Methods section. MTT formazan formation was measured at $540 \mathrm{~nm}$ by using a spectrophotometer. The growth curve of each culture was prepared by plotting the logarithmic values of $\mathrm{CFU} / \mathrm{mL}$ vs. $\mathrm{OD}_{540}$ incubation time. Results are expressed as mean \pm standard deviations of quadruplicate wells and are representative of three separate experiments. biofilms incubated with FLC at different concentrations displayed metabolic activities similar to those observed in the control biofilms (free drug). The comparative analyses of MIC and MBIC indicated that the MBIC of AMB for $12.5 \%$ (9) of C. parapsilosis complex isolates was equal to the MIC (Table III) and in $23.6 \%$ (17) of the isolates the MBIC was $\geq$ eight times higher than the MIC (Table III). The $\mathrm{MBIC}_{50}$ and $\mathrm{MBIC}_{90}$ for FLC of two Candida species were $>512 \mu \mathrm{g} / \mathrm{mL}$, while the $\mathrm{MBIC}_{50}$ and $\mathrm{MBIC}_{90}$ for $\mathrm{AMB}$ were 4 and $>16 \mu \mathrm{g} / \mathrm{mL}$, respec-
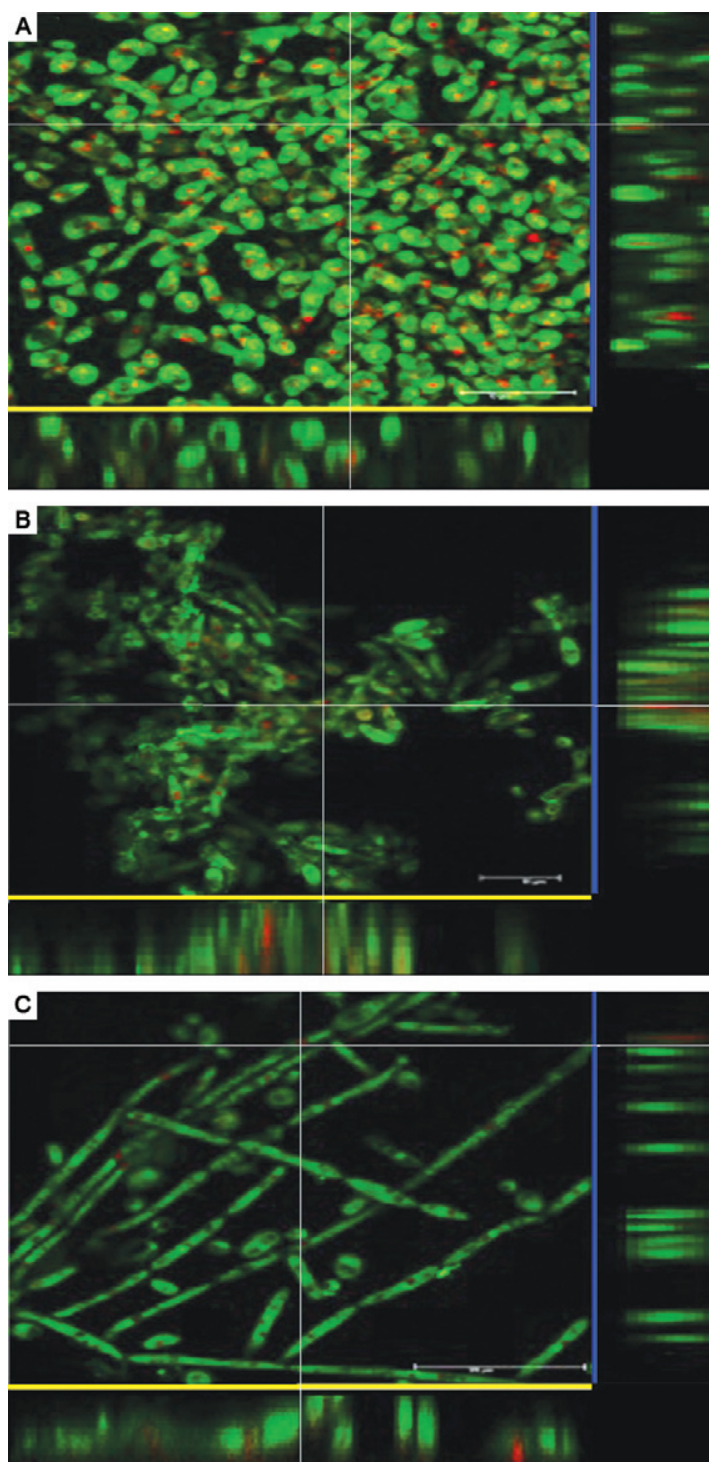

Fig. 3: confocal microscopic images of Candida orthopsilosis (A), Candida parapsilosis (B) and Candida albicans SC 5314 (C) biofilm grown on sterile polyvinylchlorid disks reveal the organization of biofilm development. Orthogonal images of Candida biofilm formation showed metabolically active (red, FUN-1-stained) cells embedded in the polysaccharide extracellular material (green, ConA-stained). For each panel (A-C), a top view of the biofilm sections is shown below the yelow line and to the right the blue line the images denote a Z-stack reconstruction. White lines indicate the location of the Z-stack sections in relation to the top view. The mature Candida biofilm reveals a complex structure with internal regions of metabolically active cells interwoven with extracellular polysaccharide material. Bar $=20 \mu \mathrm{m}$. 
tively. Quadruplicate antifungal susceptibility testing of biofilms from the same strain displayed identical MBICs for the antifungal agents tested. The MBIC for the reference strain C. albicans SC 5314 was within the range described by Pierce et al. (2008).

\section{DISCUSSION}

Dialysis fluid consists of up to $99 \%$ reverse osmosis water; in addition, chemicals such as acids, salts and bicarbonates are added. Worldwide, the production of dialysis fluid is approximately 25,000,000,000 litres, which makes dialysis fluid one of the largest products by volume used in medicine (Nystrand 2008). The microbiological content of water seldom originates in the fluid phase, i.e., the water, but on surfaces in the dialysis system (Hoenich 2009). However, water transports microbial material to dialysis machines.

We examined 100 C. parapsilosis isolates from a haemodialysis unit and by molecular analysis $53 \%$ were found to be C. parapsilosis, while $47 \%$ corresponded to $C$. orthopsilosis. In comparison to other Candida species, C. parapsilosis has an extensive distribution in nature and is not an obligate human pathogen, having been isolated from different environmental sources (Trofa et al. 2008). Those sources may represent potential routes for nosocomial transmission to patients (Kojic \& Darouiche 2004).

For haemodialysis, biofilm formation represents the starting point for biofouling, resistance to antibiotic chemotherapy or disinfection and microbial regrowth (Stewart \& Costerton 2001). Different methods for assessing Candida biofilm formation have been reported in the literature (Krom et al. 2007, Pierce et al. 2008). In this study, colorimetric evaluation showed that the absorbance readings were proportional to cell density of the biofilm in agreement with Krom et al. (2007) and
Nuryastuti et al. (2009). Small variations in the metabolic activities of the biofilm formed on the polystyrene surface were detected between the $C$. parapsilosis complex isolates tested. The results probably reflect the physiological differences between the isolates and confirm the report by Lattif et al. (2010) that all species of $C$. parapsilosis complex form equivalent biofilms.

Little information is available regarding the ability of the newly reclassified species of $C$. parapsilosis to form biofilms on biomedical substrates. In this study, a considerable number of $C$. parapsilosis $(34 / 53,64 \%)$ and $C$. orthopsilosis strains (38/47, 80.8\%) formed biofilms; this is in contrast with two previous reports in which the authors failed to demonstrate any biofilm production by these two species (Song et al. 2005, Tavanti et al. 2007). The high frequency of biofilm-producing isolates found in our study was perhaps due to a higher capacity of isolates from environmental sources to form biofilms in comparison with isolates obtained from clinical sites. In nature, fungi and pathogenic bacteria exist predominantly in biofilms, rather than as planktonic or free-floating organisms (Costerton et al. 2003, Cushion et al. 2009). Currently, the percentage of isolation of different species that constitute the complex C. parapsilosis: C. orthopsilosis, C. metapsilosis and $C$. parapsilosis have not yet been described.

Microscopy findings confirm that $C$. albicans produces more biofilm than $C$. parapsilosis species. In agreement with others researches, mature biofilms of $C$. albicans consisted of a dense network of yeast and hyphal elements (Chandra et al. 2001, Ramage et al. 2001, Seneviratne et al. 2009). Mature biofilms of C. parapsilosis are structurally similar to those described by Kuhn et al. (2002). Here, a basal blastospore layer or irregular groupings of blastospores were observed for C. parapsilosis, while C. orthopsilosis presented short filamentous forms, besides blastopores.
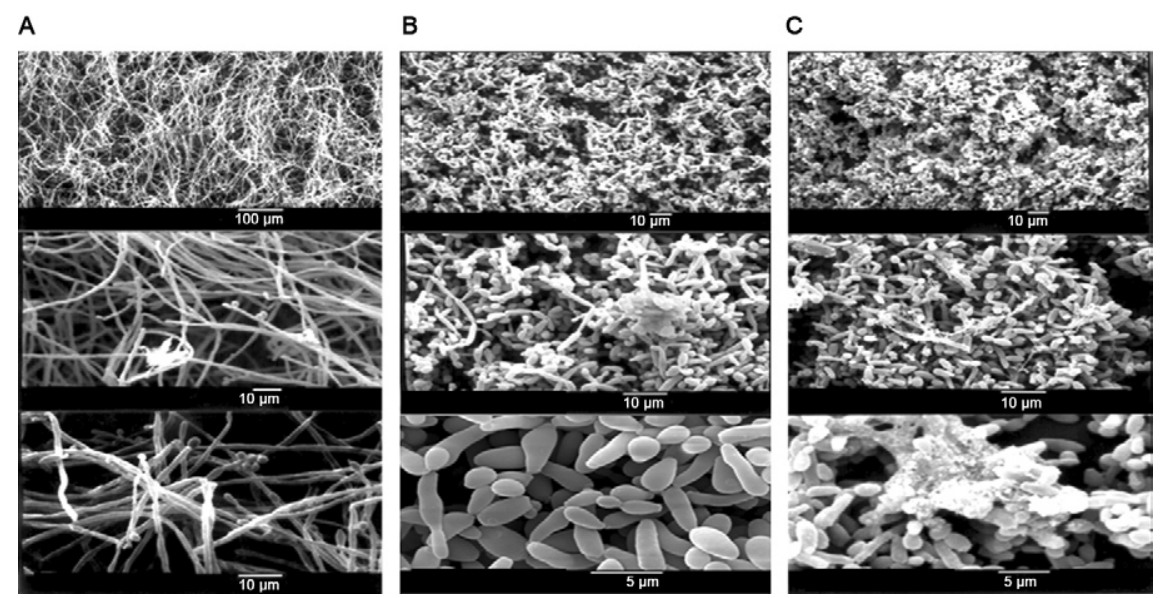

Fig. 4: scanning electron microscopy (SEM) images of Candida biofilms. Biofilms formed after 24-hour incubation in plates of 12 wells. Preparation and observation under the SEM were carried out as described in the text. The images showed thick biofilms of Candida on the surface, consisting of groups of cells separated by water channels and the extracellular matrix appears in micrographs as a fibrous network between cells. A: note a mature biofilms of Candida albicans consisted of a dense network of yeast and hyphal elements; B: representative isolate of Candida parapsilosis in dense mass of biofilm containing irregular groupings of blastospores; C: representative isolate of Candida orthopsilosis biofilm presented short filamentous forms besides blastopores. Cells are visible within the cracks on the netting. Note the extracellular matrix encapsulating cells. 
SEM and microtitre assays results demonstrated that C. parapsilosis and C. orthopsilosis form biofilms on polystyrene and PVC surfaces in accordance with the report from Rotrosen et al. (1983) that stated that both yeast cells and hyphal-form Candida can adhere to polystyrene. It is known that catheters made of synthetic polymers are more exposed to microorganisms (Delorme et al. 1992) because they promote the retention of proteins (albumin and coagulation proteins) on their surfaces, increasing adhesion and microbial proliferation (Kojic \& Darouiche 2004, Cappelli et al. 2005). Moreover, the risk of contamination to the patient is increased when considering the stagnation of flow in the tubes within the dialysis machine, which occurs during the inter-dialysis, providing ideal conditions for the adhesion, proliferation and formation of biofilm (Man et al. 1998).

Sessile (biofilm) cells display unique phenotypic traits in comparison with planktonic cells (Ramage et al. 2002). The most notable of these is that sessile cells are resistant to both antimicrobial agents and host immune factors. Our results confirm that sessile C. parapsilosis complexes are highly resistant to azoles $(>512 \mu \mathrm{g} / \mathrm{mL}$ ) as previously demonstrated by others (Ramage et al. 2002, Choi et al. 2007, Melo et al. 2011).
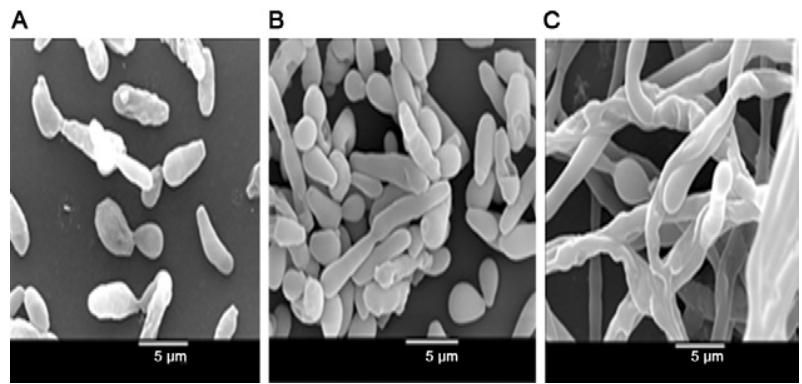

Fig. 5: scanning electron micrographs of preformed Candida biofilms in the presence of different amphotericin B (AMB) concentrations. Biofilms were grown on polyvinylchloride disks for $24 \mathrm{~h}$ prior to exposure to the antimicrobial agent; then they were incubated for $24 \mathrm{~h}$ in Roswell Park Memorial Institute 1640 medium containing different concentrations of AMB. A: Candida parapsilosis $(16 \mu \mathrm{g} / \mathrm{mL})$; B: Candida orthopsilosis (16 $\mu \mathrm{g} / \mathrm{mL})$; C: Candida albicans $(4 \mu \mathrm{g} / \mathrm{mL})$. No biofilm mass was observed.
Antifungal therapy is usually directed by the sensitivities of the organism in vitro (Tarif 2004). Although interpretive breakpoints for AMB have not been established, isolates of Candida spp for which MICs are $>1 \mu \mathrm{g} / \mathrm{mL}$ are unusual and possibly resistant or, at the very least, may require high doses of $\mathrm{AMB}(\geq 1 \mathrm{mg} / \mathrm{kg}$ of body weight/ day) for optimal treatment (Rex \& Pfaller 2002, Spellberg et al. 2006, Pappas et al. 2009). In this study, for $12.5 \%$ of $C$. parapsilosis complex isolates the MBICs of AMB were equal to the MICs (Table II) and $\geq$ eight times the MIC in $23.6 \%$ of the isolates (Table II). Similar results have been observed by Kuhn et al. (2002) and Choi et al. (2007). It has been suggested that biofilm resistance may be related to contributions from the extracellular matrix that prevent active drug diffusion, the physiological state of cell, efflux pumps on the cell membrane that pump antifungal drugs out of the cell or differential gene expression patterns by sessile cells (Chandra et al. 2001, Kuhn et al. 2002, Ramage et al. 2002, Mukherjee \& Chandra 2004, d'Enfert 2006, Seneviratne et al. 2008).

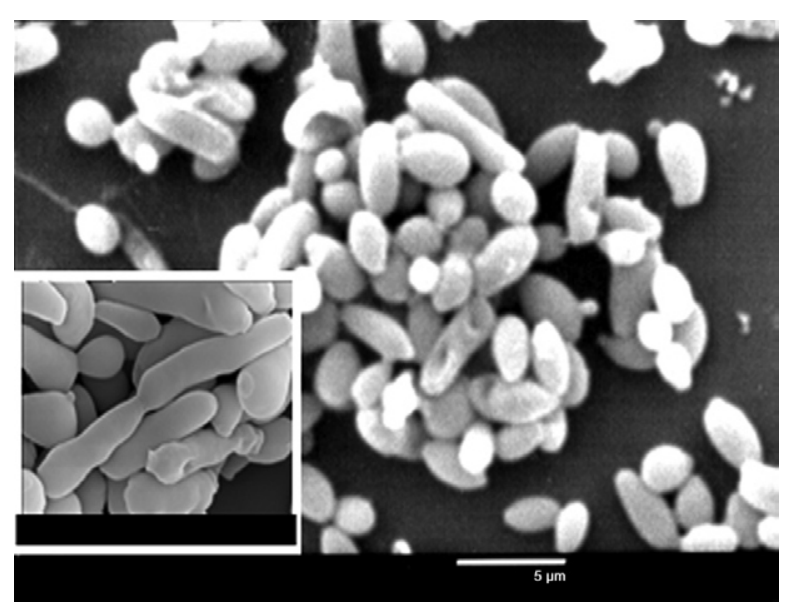

Fig. 6: scanning electron micrographs of preformed Candida parapsilosis biofilms in the presence of fluconazole. Biofilms were grown on polyvinylchloride disks for $24 \mathrm{~h}$ prior to exposure to the antimicrobial agent; then they were incubated for $24 \mathrm{~h}$ in Roswell Park Memorial Institute 1640 medium containing $512 \mu \mathrm{g} / \mathrm{mL}$. The blastospores showed minimal changes.

TABLE II

Antifungal susceptibilities of 100 Candida parapsilosis complex isolates obtained from water used in haemodialysis centre

\begin{tabular}{|c|c|c|c|c|c|c|c|c|c|c|c|}
\hline \multirow[b]{2}{*}{ Species } & \multirow{2}{*}{$\begin{array}{l}\text { Isolates } \\
\text { (n) }\end{array}$} & \multirow{2}{*}{$\begin{array}{l}\text { Antifungal } \\
\text { agent }\end{array}$} & \multicolumn{9}{|c|}{ Number inhibited at minimal inhibitory concentrations ${ }^{a}(\mu \mathrm{g} / \mathrm{mL})$} \\
\hline & & & 0.015 & 0.03 & 0.06 & 0.125 & 0.25 & 0.5 & 1 & 2 & 4 \\
\hline \multirow[t]{2}{*}{ Candida parapsilosis } & 53 & Fluconazole & & & 2 & 6 & 15 & 16 & 6 & 3 & 5 \\
\hline & & Amphotericin B & 2 & 24 & 23 & 4 & 0 & & & & \\
\hline \multirow[t]{2}{*}{ Candida orthopsilosis } & 47 & Fluconazole & & & 1 & 6 & 13 & 11 & 12 & 2 & 2 \\
\hline & & Amphotericin B & 5 & 18 & 19 & 4 & 1 & & & & \\
\hline
\end{tabular}

$a$ : according to the Clinical and Laboratory Standards Institute M27-A3 document. 
TABLE III

Relationship between minimum biofilm inhibitory concentration (MBIC) and minimal inhibitory concentration (MIC) for amphotericin B against 72 Candida parapsilosis complex isolates

\begin{tabular}{|c|c|c|}
\hline \multirow[b]{2}{*}{$\mathrm{MBIC}=\mathrm{n} \times \mathrm{MIC}^{a}$} & \multicolumn{2}{|c|}{$\begin{array}{c}\text { Isolates with MBIC } \\
\text { n-folds higher than the MIC } \\
\mathrm{n}(\%)\end{array}$} \\
\hline & $\begin{array}{l}\text { C. parapsilosis } \\
(\mathrm{n}=34)\end{array}$ & $\begin{array}{l}\text { C. orthopsilosis } \\
(\mathrm{n}=38)\end{array}$ \\
\hline $\mathrm{MBIC} \leq \mathrm{MIC}$ & $8(11.1)$ & $16(22.2)$ \\
\hline $\mathrm{MBIC}=\mathrm{MIC}$ & $6(8.3)$ & $3(4.1)$ \\
\hline $\mathrm{MBIC}=2 \times \mathrm{MIC}$ & $8(11.1)$ & $9(12.5)$ \\
\hline $\mathrm{MBIC}=4 \times \mathrm{MIC}$ & $1(1.4)$ & $4(5.6)$ \\
\hline $\mathrm{MBIC}=8 \times \mathrm{MIC}$ & $2(2.8)$ & $4(5.6)$ \\
\hline $\mathrm{MBIC}=16 \times \mathrm{MIC}$ & $5(6.9)$ & $1(1.4)$ \\
\hline $\mathrm{MBIC} \geq 16 \times \mathrm{MIC}$ & $4(5.6)$ & $1(1.4)$ \\
\hline
\end{tabular}

$a$ : MIC amphotericin $\mathrm{B}=2 \mu \mathrm{g} / \mathrm{mL}$ (Clinical and Laboratory Standards Institute M27-A3 document) (Guinea et al. 2010).

In conclusion, we observed that $C$. orthopsilsois and C. parapsilsosis were contaminating the water used in the haemodialysis unit studied. Among the strains tested, most were able to produce biofilm. In evaluating the sensitivity of the biofilms to antifungal agents in clinical use, we saw that all isolates studied were resistant to FLC and the majority were resistant to AMB. It is particularly important in dialysis to prevent the formation of biofilm, because the reduced availability of nutrients and accumulation of toxic waste encourages the dispersal of cells, i.e., the release of cells from the original biofilm community to generate new communities in new places (Uppuluri et al. 2010). Dispersed cells of Candida are responsible for candidemia and invasive disseminated candidiasis, which are among the most serious forms of infection and lead to the highest mortality rates (Colombo et al. 2006, Bruder-Nascimento et al. 2010).

\section{ACKNOWLEDGEMENTS}

To Prof. Arnaldo Lopes Colombo, for C. albicans SC5314, C. parapsilosis ATCC 90018, C. orthopsilosis ATCC 96141 and C. metapsilosis ATCC 96143 strains.

\section{REFERENCES}

APHA - American Public Health Association 2005. Standard methods for the examination of water and wastewater, APHA, Washington, $41 \mathrm{pp}$.

Berridge MV, Herst PM, Tan AS 2005. Tetrazolium dyes as tools in cell biology: new insights into their cellular reduction. Biotechnol Апnи Rev 11: 127-152.

Bruder-Nascimento A, Camargo CH, Sugizaki MF, Sadatsune T, Montelli AC, Mondelli AL, Bagagli E 2010. Species distribution and susceptibility profile of Candida species in a Brazilian public tertiary hospital. BMC Res Notes 3: 3:1.

Cappelli G, Tetta C, Canaud B 2005. Is biofilm a cause of silent chronic inflammation in haemodialysis patients? A fascinating working hypothesis. Nephrol Dial Transp 20: 266-270.
Chandra J, Mukherjee PK, Leidich SD, Faddoul FF, Hoyer LL, Douglas LJ, Ghannoum MA 2001. Antifungal resistance of candidal biofilms formed on denture acrylic in vitro. J Dent Res 80: 903-908.

Choi HW, Shin JH, Jung SI, Park KH, Cho D, Kee SJ, Shin MG, Suh SP, Ryang DW 2007. Species-specific differences in the susceptibilities of biofilms formed by Candida bloodstream isolates to echinocandin antifungals. Antimicrob Agents Chemother 51: 1520-1523.

CLSI - Clinical and Laboratory Standards Institute 2008. Reference method for broth dilution antifungal susceptibility testing of yeasts. Approved standard M27-A3, 3rd ed., CLSI, Wayne, 33 pp.

Colombo AL, Nucci M, Park BJ, Nouér SA, Arthington-Skaggs B, da Matta DA, Warnock D, Morgan J, Brazilian Network Candidemia Study 2006. Epidemiology of candidemia in Brazil: a nationwide sentinel surveillance of candidemia in eleven medical centers. J Clin Microbiol 44: 2816-2823.

Cordeiro RA, Brilhante RS, Pantoja LD, Moreira Filho RE, Vieira PR, Rocha MF, Monteiro AJ, Sidrim JJ 2010. Isolation of pathogenic yeasts in the air from hospital environments in the city of Fortaleza, Northeast Brazil. Braz J Infect Dis 14: 30-34.

Costerton JW, Lewandowski Z, Caldwell DE, Korber DR, Lappin-Scott HM 2003. Microbial biofilms. Annu Rev Microbiol 49: 711-745.

Cushion MT, Collins MS, Linke MJ 2009. Biofilm formation by Pneumocystis spp. Eukaryot Cell 8: 197-206.

d'Enfert C 2006. Biofilms and their role in the resistance of pathogenic Candida to antifungal agents. Curr Drug Targets 7: 465-470.

Delorme JM, Guidoin R, Canizales S, Charara J, How T, Marois Y, Batt M, Hallade P, Ricci M, Picetti C 1992. Vascular access for hemodialysis: pathologic features of surgically excised ePTFE grafts. Ann Vasc Surg 6: 517-524.

Diekema DJ, Messer SA, Boyken LB, Hollis RJ, Kroeger J, Tendolkar S, Pfaller MA 2009. In vitro activity of seven systemically active antifungal agents against a large global collection of rare Candi$d a$ species as determined by CLSI broth microdilution methods. J Clin Microbiol 47: 3170-3177.

Drozdowska A 2007. Morphological and biochemical features of fungi isolated from patients with renal failure. Wiad Parazytol 53: $145-148$.

Guinea J, Recio S, Escribano P, Torres-Narbona M, Peláez T, Sánchez-Carrillo C, Rodríguez-Créixems M, Bouza E 2010. Rapid antifungal susceptibility determination for yeast isolates by use of Etest performed directly on blood samples from patients with fungemia. J Clin Microbiol 48: 2205-2212.

Hoenich NA 2009. Disinfection of the hospital water supply: a hidden risk to dialysis patients. Crit Care 13: 1007.

Kojic EM, Darouiche RO 2004. Candida infections of medical devices. Clin Microbiol Rev 17: 255-267.

Krom BP, Cohen JB, Feser GEM, Cihlar RL 2007. Optimized candidal biofilm microtiter assay. J Microbiol Methods 68: 421-423.

Kuhn DM, George T, Chandra J, Mukherjee PK, Ghannoum MA 2002. Antifungal susceptibility of Candida biofilms: unique efficacy of amphotericin B lipid formulations and echinocandins. Antimicrob Agents Chemother 46: 1773-1780.

Kurtzman CP, Fell JW 1998. The yeasts: a taxonomic study, Elsevier, Amsterdam, $2354 \mathrm{pp}$.

Lattif AA, Mukherjee PK, Chandra J, Swindell K, Lockhart SR, Diekema DJ, Pfaller MA, Ghannoum MA 2010. Characterization of biofilms formed by Candida parapsilosis, C. metapsilosis and C. orthopsilosis. Int J Med Microbiol 300: 265-270.

Man NK, Degremont A, Darbord JC, Collet M, Vaillant P 1998. Evidence of bacterial biofilm in tubing from hydraulic pathway of hemodialysis system. Artif Organs 22: 596-600. 
Marion-Ferey K, Pasmore M, Stoodley P, Wilson S, Husson GP, Costerton JW 2003. Biofilm removal from silicone tubing: an assessment of the efficacy of dialysis machine decontamination procedures using an in vitro model. $J$ Hosp Infect 53: 64-71.

Medrano DJA, Brilhante RSN, Cordeiro RA, Rocha MFG, Rabenhorst SHB, Sidrim JJC 2006. Candidemia in a Brazilian hospital: the importance of Candida parapsilosis. Rev Inst Med Trop Sao Paulo 48: 17-20.

Melo AS, Bizerra FC, Freymüller E, Arthington-Skaggs BA, Colombo AL 2011. Biofilm production and evaluation of antifungal susceptibility amongst clinical Candida spp isolates including strains of the Candida parapsilosis complex. Med Mycol 49: 253-262.

Mukherjee PK, Chandra J 2004. Candida biofilm resistance. Drug Resist Updat 7: 301-309.

Nucci M, Queiroz-Telles F, Tobón AM, Restrepo A, Colombo AL 2010. Epidemiology of opportunistic fungal infections in Latin America. Clin Infect Dis 51: 561-570.

Nuryastuti T, van der Mei HC, Busscher HJ, Iravati S, Aman AT, Krom BP 2009. Effect of cinnamon oil on icaA expression and biofilm formation by Staphylococcus epidermidis. Appl Environ Microbiol 75: 6850-6855.

Nystrand R 2008. Microbiology of water and fluids for hemodialysis. J Clin Med Assoc 71: 223-229.

Pappas PG, Kauffman CA, Andes D, Benjamin DKJr, Calandra TF, Edwards JEJr, Filler SG, Fisher JF, Kullberg BJ, Ostrosky-Zeichner L, Reboli AC, Rex JH, Walsh TJ, Sobel JD 2009. Clinical practice guidelines for the management of candidiasis: 2009 update by the Infectious Diseases Society of America. Clin Infect Dis 48: 503-535.

Pereira GH, Müller PR, Szeszs MW, Levin AS, Melhem MS 2010. Five-year evaluation of bloodstream yeast infections in a tertiary hospital: the predominance of non-C. albicans Candida species. Med Mycol 48: 839-842.

Pfaller MA, Diekema DJ, Messer SA, Boyken L, Hollis RJ 2003. Activities of fluconazole and voriconazole against 1,586 recent clinical isolates of Candida species determined by Broth microdilution, disk diffusion and Etest methods: report from the ARTEMIS Global Antifungal Susceptibility Program 2001. J Clin Microbiol 41: 1440-1446.

Pierce CG, Uppuluri P, Tristan AR, Wormley JR FI, Mowat E, Ramage G, Lopez-Ribot JL 2008. A simple and reproducible 96well plate-based method for the formation of fungal biofilms and its application to antifungal susceptibility testing. Nat Protoc 3: 1494-1500.

Pires-Gonçalves RH, Sartori FG, Montanari LB, Zaia JE, Melhem MSC, Mendes-Giannini MJS, Martins CHG 2008. Occurrence of fungi in water used at a haemodialysis centre. Lett Appl Microbiol 46: 542-547.

Ramage G, Bachmann S, Patterson TF, Wickes BL, López-Ribot JL 2002. Investigation of multidrug efflux pumps in relation to fluconazole resistance in Candida albicans biofilms. Antimicrob Agents Chemother 49: 973-980.

Ramage G, Walle KV, Wickes BL, López-Ribot JL 2001. Standardized method for in vitro antifungal susceptibility testing of Candida albicans biofilms. Antimicrob Agents Chemother 45: 2475-2479.

Reasoner DJ, Geldreich EE 1985. A new medium for the enumeration and subculture of bacteria from potable water. Appl Environ Microbiol 49: 1-7.
Reed SJB 1996. Electron microprobe analysis and scanning electron microscopy in geology, Cambridge University Press, New York, $201 \mathrm{pp}$.

Rex JH, Pfaller MA 2002. Has antifungal susceptibility testing come of age? Clin Infect Dis 35: 982-989.

Rotrosen D, Gibson TR, Edwards JE Jr 1983. Adherence of Candida species to intravenous catheters. J Infect Dis 147: 594.

Schindler R, Beck W, Deppisch R, Aussieker M, Wilde A, Göhl H, Frei U 2004. Short bacterial DNA fragments: detection in dialysate and induction of cytokines. J Am Soc Nephrol 15: 3207-3214.

Seneviratne CJ, Jin L, Samaranayake LP 2008. Biofilm lifestyle of Candida: a mini review. Oral Dis 14: 582-590.

Seneviratne CJ, Silva WJ, Jin LJ, Samaranayake YH, Samaranayake LP 2009. Architectural analysis, viability assessment and growth kinetics of Candida albicans and Candida glabrata biofilms. Arch Oral Biol 54: 1052-1060.

Silva AP, Miranda IM, Lisboa C, Pina-Vaz C, Rodrigues AG. 2009. Prevalence, distribution and antifungal susceptibility profiles of Candida parapsilosis, C. orthopsilosis and C. metapsilosis in a tertiary care hospital. J Clin Microbiol 47: 2392-2397.

Song JW, Shin JH, Shint DH, Jung SI, Cho D, Kee SJ, Shin MG, Suh SP, Ryang DW 2005. Differences in biofilm production by three genotypes of Candida parapsilosis from clinical sources. Med Mycol 43: 657-661.

Spellberg BJ, Filler SG, Edwards JE Jr 2006. Current treatment strategies for disseminated candidiasis. Clin Infect Dis 42: 244-251.

Stewart PS, Costerton JW 2001. Antibiotic resistance of bacteria in biofilms. Lancet 358: 135-138.

Tarif N 2004. Candida lusitaniae peritonitis in a chronic ambulatory peritoneal dialysis patient. Saudi J Kidney Dis Transpl 15: 170-173.

Tavanti A, Davidson AD, Gow NA, Maiden MCJ, Odds FC 2005. Candida orthopsilosis and Candida metapsilosis spp nov. to replace Candida parapsilosis groups II and III. J Clin Microbiol 43: 284-292.

Tavanti A, Hensgens LA, Ghelardi E, Campa M, Senesi S 2007. Genotyping of Candida orthopsilosis clinical isolates by amplification fragment length polymorphism reveals genetic diversity among independent isolates and strain maintenance within patients. J Clin Microbiol 45: 1455-1462.

Trofa D, Gácser A, Nosanchuk JD 2008. Candida parapsilosis, an emerging fungal pathogen. Clin Microbiol Rev 21: 606-625.

Upppuluri P, Chaturvedi AK, Srinivasan A, Banerjee M, Ramasubramaniam AK, Köhler JR, Kadosh D, Lopez-Ribot JL 2010. Dispersion as an important step in the Candida albicans biofilm developmental cycle. PLoS Pathog 6: e1000828.

Varo SD, Martins CHG, Cardoso MJO, Sartori FG, Montanari LB, Pires-Gonçalves RH 2007. Isolamento de fungos filamentosos em água utilizada em uma unidade de hemodiálise. Rev Soc Bras Med Trop 40: 326-331.

Vorbeck-Meister I, Sommer R, Vorbeck F, Horl WH 1999. Quality of water used for haemodialysis: bacteriological and chemical parameters. Nephrol Dial Transplant 14: 666-675.

Yang YL, Ho YA, Cheng HH, Ho M, Lo HJ 2004. Susceptibilities of Candida species to amphotericin B and fluconazole: the emergence of fluconazole resistance in Candida tropicalis. Infect Control Hosp Epidemiol 25: 60-64. 